\title{
CEACAM8 wt Allele
}

National Cancer Institute

\section{Source}

National Cancer Institute. CEACAM8 wt Allele. NCI Thesaurus. Code C118589.

Human CEACAM8 wild-type allele is located in the vicinity of $19 q 13.2$ and is approximately $15 \mathrm{~kb}$ in length. This allele, which encodes carcinoembryonic antigen-related cell adhesion molecule 8 protein, may be involved in immune cell activation. 